\title{
THE RIVER BECOMES THE MEDIATOR - URBAN RIVER RESTORATION CREATING NEW SPACES FOR INTERCULTURAL DIALOGUE AND MEDIATION
}

\author{
Paul Chapman
}

\begin{abstract}
At a basic level, water is a fundamental part of the human experience. Cities are, for the most part, founded on rivers. Water and rivers form a significant metaphor in describing, recording and celebrating historic and personal narratives. The title of this paper is inspired by a Persian fairy tale where a lovelorn princess, needing reassurance that the man she had fallen in love with was true, spoke to and heard back from the river. Symbolised by the river, water is the bringer of life and the connector of people. And yet... in many cities the small urban river is a problem, something to be fenced off and ignored. While cities have rediscovered the importance of major rivers in driving regeneration, smaller tributaries, streams and creeks are covered, diverted or hidden away. But it doesn't take much for the focus to change. Revitalised riparian public spaces provide a natural and neutral meeting point for all members of the community with the river acting as a physical and metaphorical mediator. Previously unloved and unknown spaces can become a key part of a city's infrastructure. More importantly, the city residents have a space to meet becoming, in turn, known and loved.
\end{abstract}

\section{O RIO COMO MEDIADOR - A RECUPERAÇÃO DE RIOS URBANOS PARA CRIAR NOVOS ESPAÇOS DE MEDIAÇÃO E DE DIÁLOGO INTERCULTURAL}

\begin{abstract}
RESUMO
Num nível básico, a água é uma parte essencial da experiência humana. Na maioria das vezes, as cidades são fundadas onde existem rios. A água e os rios são uma importante metáfora na descrição, no registo e na celebração das narrativas históricas e pessoais. O título deste artigo inspira-se num conto de fadas persa, no qual uma princesa apaixonada, que precisava de saber que o homem pelo qual se tinha apaixonado era verdadeiro, falava com o rio e ouvia-o. A água, simbolizada pelo rio, é portadora da vida e uma ligação entre as pessoas. E, contudo, em muitas cidades os pequenos rios urbanos são vistos como um problema, algo vedado e ignorado. As cidades redescobriram a importância dos rios principais, mas os pequenos afluentes, os riachos e as ribeiras são cobertos, desviados ou escondidos. Contudo, não é preciso muito para alterar o foco. Os espaços públicos ribeirinhos oferecem um ponto de encontro natural e neutro para todos os membros da comunidade, nos quais o rio atua como um mediador físico e metafórico. Espaços desconhecidos e pouco queridos podem tornar-se parte das infraestruturas da cidade. E mais importante, os habitantes da cidade ganham um espaço de encontro que assim se torna conhecido e querido.
\end{abstract}




\section{INTRODUCTION}

What has a river got to do with intercultural dialogue and mediation? How can a river be seen as a way of encouraging intercultural engagement? The last few years have seen a significant change. Urban authorities such as Seoul in South Korea, and San Francisco in the US and Lewisham in south east London have turned the situation on its head, rerouting and revitalising large and small rivers, de-canalising and re-naturalising them and in so doing, creating vibrant, natural and welcoming spaces that put the environment at the heart of the city. In some cases, the benefits for people have been seen as secondary to the benefits for nature, in others this has been reversed. In Lewisham the interaction between people and nature has been of benefit to both; kingfishers and herons are regularly seen in the heart of the urban environment, while the residents of each city have reclaimed what were previously underused and unsafe spaces, giving them a new lease of life with people at the heart.

The experience of Lewisham (London, UK), among many others across the world, provides a context to respond to these questions. It has a population of nearly 300.000 anticipated to grow by $10 \%$ over the next 20 years. It covers around $36 \mathrm{~km}^{2}$ and is situated only five kilometres from the tourist sites of central London and the South Bank. It is designated as an Inner London borough and includes areas of deprivation that can be found in the worst $10 \%$ across the UK. The demographics show a Black and Minority Ethnic (BAME) population of nearly $50 \%$ from a mix of backgrounds including the Caribbean, West Africa and Southeast Asia. Clearly any work carried out in the area needed to be designed to impact residents as a whole with specific efforts made to include those who were not clearly represented.

Fourteen percent of Lewisham' is made up of green spaces and parks, complemented by the three rivers that make up the lower reaches of the Ravensbourne catchment: the Ravensbourne itself, the river Pool and the fantastically named river Quaggy. Access to quality open space has been a key ambition of the Lewisham Local Plan ${ }^{2}$ which in turn follows the wider ambitions of the Greater London Authority and Mayor for London 3 .

Ladywell Fields in Lewisham is today a much loved, award winning community asset. On a typical summer weekend, the park is full of families with the young and the old enjoying a piece of countryside hidden in the middle of this London borough. Even on a cold, wet winter's day joggers and cyclists will hurry past while the occasional brave soul

\footnotetext{
'Information retrieved from the Natural capital accounts for public green space in London. Report prepared for Greater London Authority, National Trust and Heritage Lottery Fund (2017, October). Available at https://www.london.gov.uk/sites/ default/files/11015viv_natural_capital_account_for_london_v7_full_vis.pdf

2 QUERCUS in Lewisham. Evaluation Report (2018, August). Available at http://www.pceuconsultant.eu/uploads/files/ QUERCUS\%20in\%2oLewisham\%20Evaluation\%2oReport(1).pdf

${ }^{3}$ London Plan, available at https://www.london.gov.uk/what-we-do/planning/london-plan/current-london-plan
} 
can be seen surveying the scene from the warmth of the Community Cafe. After school, the park becomes a destination for teenagers heading for the skatepark, with families with young children using the two well-kept play areas, and when it's warm, paddling in the river itself. At the height of the Wimbledon Tennis Championships there is often a queue of people waiting to use the newly refurbished courts. Biodiversity and local history volunteers organise informative walks through the park. There are opportunities for joining River Clean Ups or helping manage the nature reserves. Occasionally on a hot summer's evening, local groups organise river-related community theatre and storytelling activities. It is a fantastic example of what can happen when different agencies and departments work together to achieve multiple benefits. Yet not all of this was planned or even anticipated, and the links between the natural environment and intercultural opportunities were barely considered, but there were a lot of lessons learnt, most importantly by a team of people committed to making their borough better.

In 2005 , this was most definitely not the case. Ladywell Fields was an unremarkable, disjointed "metropolitan" park, established by law in the late $18800^{4}$. Situated between Ladywell Station, the District Hospital and the edge of Lewisham Town Centre, the northern section of the park was seen as an unavoidable shortcut between transport links and workplaces, somewhere to get through as quickly as possible and definitely not a place to stop for any longer than was necessary. There were one-off and standalone attempts to address the problem, a factor that led to a lit pathway across the park being added, but overall it was acknowledged that a more comprehensive approach was needed.

\section{DESIGNING OUT CRIME}

With access to open space becoming more pressured, a programme of upgrading Lewisham's parks to meet national Green Flag Award's status was implemented. In a 2003 crime prevention report produced by the Metropolitan Police (no longer available) - the project team noticed a significant gap in a section on parks and open spaces where nothing was submitted under the heading for river corridors. As a summary, the police favoured an approach known as Designing out crime, which, while successful in the built environment was untested as a methodology in natural open spaces. The key principle of Designing out crime is to provide clearly marked exits, entrances and lines of sight, usually in the development of residential or hard built public areas. In addition, it uses the idea of people "policing" the space that they act as the eyes and ears of an area. Greater numbers of people, rather than creating problems, make the space safer as there is less chance for opportunistic crime.

\footnotetext{
4 History of Ladywell, available at https://www.lewisham.gov.uk/inmyarea/history/local-history/Documents/LadywellLocalHistory.pdf

${ }^{5}$ Available at http://www.greenflagaward.org.uk/park-summary/?park=859
} 


\section{THE RIVER RAVENSBOURNE}

The river Ravensbourne became the focus of the proposed societal and environmental improvements to Ladywell Fields. The Ravensbourne catchment covers four different London boroughs: surfacing at Keston Ponds in Bromley with other tributaries in Croydon and Greenwich, the downstream section of the catchment flows from the south of Lewisham through to joining the Thames at Deptford. The history of the river can be seen in some of the modern place names reflecting its industrial past; Cornmill, Glassmill and Watermill. Deptford was the base for the British Navy in the reign of Henry VIII, its "Deep Ford" providing the space needed to build and equip the ships of the period. In the late $17^{\text {th }}$ century, Peter the Great of Russia and his entourage famously drank Deptford dry during a visit to learn shipbuilding skills.

As the borough expanded, the rivers became less relevant, in some cases becoming little more than drains. In turn this led to developments which were built backing onto the river channel, while in other cases the river was culverted in concrete channels or simply covered over. Severe floods in 1968 that impacted most of the borough seemed to come as a surprise and led to even more culverting and fencing off in keeping with the thinking at the time.

\section{LADYWELl FieldS}

In Ladywell Fields the main channel of the river Ravensbourne runs around the edge of the park and was sectioned off by an iron railing and hidden behind overgrown trees and shrubs. The unintentional message given was "keep out, this river is a problem and should be avoided". In fact, most residents, when asked about the initial plans for the park, responded with "what river?". While the secluded waterway provided a haven for wildlife, it was not contributing to the key objectives of any public park.

As with any major scheme in a public space the first step was to canvass public opinion. The initial questionnaires uncovered some deep-seated unease with the park as it was. People didn't use it primarily because they didn't feel safe; nearly $80 \%$ responded that they felt this way ${ }^{6}$. Knowing that Ladywell Fields was perceived as unsafe, the project team saw the potential of testing the transferability of the Designing out crime concept to the park. Could the park be made safer by implementing and adapting some of the recommendations? How would people respond to the changes? How would this impact biodiversity?

The initial plans for Ladywell Fields submitted as part of a funding bid to the EU's LIFE Environment fund in 2005 , consisted of making clearer sight lines and removing the physical barriers to the river. But transferring the concept of Designing out crime meant that this had to be achieved without removing trees which may have impeded the sight lines particularly because they are an integral part of any park, and it was already known to be an action that would raise public objections. This meant that the main aim of the

${ }^{6}$ QUERCUS in Lewisham. Evaluation Report (2018, August). Available at http://www.pceuconsultant.eu/uploads/files/ QUERCUS\%20in\%20Lewisham\%20Evaluation\%2oReport(1).pdf 
proposed project was to remove the fencing along the river corridor and bring the river back into the everyday provision of the park. There were general discussions about access to the water, vandalism, and inevitable local government concerns about health and safety - one of the initial reasons for fencing off the river was the perceived risk of accident and potential drowning.

However, the public consultation exercises also came up with something much more adventurous and set the tone for the engagement of people in the process. They countered the health and safety concerns with assertions that allowing people contact with the river provided a learning context of how to deal with water. There were anecdotal accounts of childhoods spent wading, fishing and catching tadpoles and a wish that the younger generations should be allowed this opportunity.

The plans they came up with, developed and designed with support from landscape architects BDP, were to transform the park by adding a secondary river channel through the centre of the northern field. This approach turned the process from purely natural solution to one led by people. Ongoing work included an Equalities Impact Assessment and a clear understanding that the results of the work needed to be shared with and used by all parts of the community; the "what river?" had become "our river".

The Delivery Team also joined forces with external agencies that had a stake in the process, most notably the Environment Agency, who in England are the managing authority for the water itself, the river bed and river banks. By combining resources and questionnaires, the joint approach aimed to avoid "consultation fatigue" and not only welcomed comments and questions but provided tea, coffee and ice cream in return. The consultation process followed normal Council procedure to identify and engage with as many stakeholders as possible. Given the open access policy of parks and green space, this meant thinking more widely about the groups and individuals that needed to be included, so the team responsible looked at alternative arrangements and opportunities. This helped change the focus of the interventions, providing a way of harnessing the good will and interest that the project generated.

One arrangement that sticks in the mind was using a planned visit by Archbishop Desmond Tutu to open a new wing of the hospital adjacent to the park. The team saw an opportunity to promote the plans and gauge reaction from hospital users who tended to use the park as a cut through from the railway station but may otherwise have not been spoken to. The event, which was held in Ladywell Fields, provided an opportunity to show people the physical space, explain the plans and get first hand responses. Other consultation opportunities came about by chance or through the fact that staff were often onsite because of the physical nature of the project. One of these involved a member of the Lewisham Disability Forum who had heard that due to the illegal riding of motorbikes through the park, the entrances were going to be fenced off, with the unintended impact of blocking access to those in wheelchairs. The team were able to feed this into the Designing out crime model and agreed that the main entrance would not be gated, and more than that would act as a welcoming entrance to the park. In reality, the motorbike issue was a summer fad and, following the reopening of the park, was rarely 
mentioned again as an issue.

Central to the new purpose for the park was a small café, which while open for much of the year, struggled to survive. Designing out crime focuses on the additional value of people being present to act as "eyes and ears" and a cafe provides a ready-made reason for people to be present. Unfortunately, at the time, and in keeping with the general perceptions of the area, the existing building was prone to break ins and vandalism. Originally part of the railway station, it was accessible from all sides. However, the owner was determined to stay and make a difference in the locality and saw the proposed works to the park as an opportunity. The situation was partly resolved through a most unexpected source.

As part of the wider plans for improving the park and providing reasons for people of all ages to be there, the Lewisham Youth Service worked in partnership with the park's team to construct a skateboard park. Alongside the tennis courts and children's play areas already on site, this move was aimed at improving facilities for all age groups and particularly - in response to their requests - the teenage and young adult population. The decision raised a few eyebrows not least from the project funder who initially struggled to see the link between a skatepark and the natural environment. Also, given the drive to Design out crime, there was a general, but ultimately unfounded, concern that attracting groups of young people would only create the problems the project was trying to solve.

However, the skaters and cafe owner formed an unlikely yet remarkable partnership. The skater's bumps and bruises needed ice to aid recovery. The cafe had plenty of ice and the owner was more than happy to provide it free of charge. The young people then started using the cafe, buying drinks and snacks and more importantly building up a relationship with the café owner. The custom helped with the viability of the café, but also created a natural reason for the young people to mix with the other park users. From this point on, for at least 10 years, there was an equally remarkable impact. There were no reported break-ins, thefts or acts of vandalism at the park cafe. The combination of a committed and community-focused cafe owner, in conjunction with providing resources for young people, rather than accentuating problems and differences, had the result of Designing out crime and beginning to create a safer space.

The Ladywell Fields Park user group were also central to the ongoing discussions, debates and positive responses to the plans for rerouting the river. Not only did they see and support the rationale from decisions such as improving the cafe and installing the skatepark, but they were fully behind the ideas for the river. Their influence and the ongoing involvement of the user group in all aspects of the redevelopment meant that their membership, a mix of local residents and community groups, were up to speed with all the issues, partners and possibilities offered by the work. Their ambition was to turn Ladywell Fields into a destination for local residents, somewhere that they wanted to visit and spend time.

It is also worth mentioning the impact of changes to the main entrance to the park. Situated on the apex of a road bridge crossing the railway and river, the first thing a visitor would see was an untidy, uncared for copse of trees preventing any view across the park. Given the central aim of the Designing out crime concept, an obvious solution was 
removing the trees. The delivery team soon discovered, however, how emotive this sort of action could be. While people wanted a better park, it should not be at the expense of the trees. What replaced it had to be better and take concerns into account.

Visitors to Ladywell Fields today enter a clearly signed entrance, with seating, signing, a beautiful wooden name marker and most importantly a fantastic view across the park with the new river channel central. A key aspect of Designing out crime is providing clear lines of sight and a variety of options for people to use. From the new entrance it is possible to see right to the far end of the northern field. On advice from the Council's Tree Officer, the silver birches that formed the former untidy copse were carefully replanted either side of the entrance to compliment and tree-line the path.

The original paths and access arrangements were a key reason in people's responses of why they felt unsafe. While there was a direct link from the station platform to the park, this was by a poorly-lit, high-fenced pathway, where at the top it would be relatively easy for someone to stay out of sight. The new layout provided a second route off the platform; it took away the barrier on one side and in doing so created clear sight lines without taking out the mature trees in the area. New paths were laid, and sympathetic lighting introduced, all of which greatly added to creating a safer environment. They have clearly marked exits and entrances leading to the town centre and hospital, while the access to and from the railway station has been transformed beyond recognition.

One area that the delivery team invested a lot of time and person hours in were links to children and their schools. There was already a programme of "outdoor classrooms" in place that were added to by the newly repurposed Ladywell Fields. Lessons on the water cycle or the life of rivers could now take place in situ. Local schools who previously had hired coaches to take their students to "nature centres" on the outskirts of London could now simply walk down the road. The Council invested in nets, waders and water monitoring equipment to allow the classes to get into the river and experience rather than just read about it in a book. In another new approach, staff ensured that this equipment was also available at weekends, actively encouraging visitors to get in to the new river channel. This had an additional impact of involving and informing residents. One report was from a parent who refused to believe that there was a river in Ladywell and thought their child must have been mistaken. They visited the next weekend to find out the reality for themselves. The river was becoming part of people's lives and the people visiting the river and park were becoming part of each other's. The vision of seeing the park full and well used started to become a reality within days of the new river channel opening. The visual impact of water flowing through the middle of the park was very difficult to miss. People who used to get through the park as quickly as possible stopped to look at and take in their new surroundings.

One of the biggest questions raised by stakeholders and the public was in regard to the potential impact on biodiversity. Surely by encouraging people to use the park the flora and fauna, which until then had been relatively undisturbed, would be decimated by the increased footfall. Surprisingly the opposite was true. Where there had once been a grassed open field there was now a river channel with graded banks, a backwater pond 
and a specially planted wildflower meadow. A greater diversity of natural habitats brought a greater diversity of species into the park. During a visit by the EU LIFE monitoring team early on in the life of the project, their trained experts were spotting plants, birds, insects and animals that they were amazed to find in an urban setting. The Council's Biodiversity Officer decided that the new river channel should be "self seeding", that only plants washed downstream that then took hold should green the banks. There would be no planting unless it was needed to protect the banks. This meant that although the process took time to bed in, the new channel had a very natural feel from the beginning. All of this added to its attraction and the growing realisation that on an environmental scale something very special was happening.

Surveys carried out after the works were completed 7 showed that there was now twice the amount of biodiversity in the park. Herons, kingfishers and even little egrets became regular visitors, all attracted by the increased numbers of fish in the river. Fish such as chubb and dace were restocked and monitored by the Environment Agency and thrived in the improved river. This was backed up by a significant improvement in the water quality of the river Ravensbourne. This was not something that the delivery team had even discussed at the beginning of the project, but as they got to understand the priorities of their key partner, the Environment Agency, the value of this information came into its own. From an environmental perspective there is still a debate about the value of restoring rivers in urban areas, predominantly because of the perceived lack of impact on water quality. However, ongoing analysis ${ }^{8}$ showed a significant improvement - from poor to good - in the water quality of the river. This was important because it began to create an argument within the water community that to that point had been ignored - that improving urban rivers was an effective way of reaching the ambitious targets on water quality set by the EU through the Water Framework Directive.

In addition, it began to address one of the central issues of environmental improvements: what happens when people get involved? The answer from Ladywell Fields was resoundingly positive. Residents joined organised "clean up days". Any pollution, flooding or flow incidents in the river were reported immediately as the number of interested "eyes and ears", the number of people that "owned" their river, had increased. There was raised interest in the biodiversity of the park, with children taking their lessons in situ and hearing about the water cycle alongside the fact that their park provided a safe haven for bats. In another example that showed how ownership could have a significant interest, pupils who were at risk of exclusion from the local secondary school adjacent to the site, were invited to spend time in the park building bird boxes - so learning practical skills. In ongoing conversations, it was clear that these young people then took personal responsibility for "their" boxes and vandalism and anti-social behaviour decreased with their engagement.

In writing this paper, the discussions between seemingly unconnected issues

\footnotetext{
7 See QUERCUS in Lewisham. Evaluation Report (2018, August). Available at http://www.pceuconsultant.eu/uploads/files/ QUERCUS\%20in\%2oLewisham\%20Evaluation\%20Report(1).pdf
}

${ }^{8}$ Available at http://environment.data.gov.uk/catchment-planning/OperationalCatchment/3369/Summary 
opened the door to the Intercultural aspect of the paper's title. When the project started there was little more driving it than a desire to get user numbers to grow. However, from the day the new river channel opened it was obvious that something much more interesting was happening. Ladywell Fields had become a destination for all parts of the community, and more than that, they felt safe and comfortable using it. They would happily start conversations with people sitting at the next table to them in the cafe. Their children would naturally play together in the water leading to conversations between parents. The user group encouraged a number of different activities, all of which were well subscribed, providing a structured environment for strangers to work together cleaning up rubbish or clearing invasive species from the river bank. The river, and by association the park, became the property of everyone, with the natural environment becoming the backdrop for interaction and dialogue beyond the day to day. But did the project meet it objectives? How was the delicate balance between people and nature upheld? Can an urban river really encourage intercultural dialogue?

\section{THE RESULTS}

In short, the answer to all these questions is overwhelmingly positive. The project delivered far more than was ever anticipated and in doing so continues to capture the attention not only of locals, but regional, national and international experts. The blend of people and nature in an urban setting has influenced thinking on how to approach both river restoration and societal problems. The multiple benefits of the approach are only now starting to be fully understood.

Starting with the original premise for the project Designing out crime, what was the impact of the project on the people that use the park? On one level, it could be said that very little had changed; there was still the same number of recorded incidents of crime. However, there had been an increase of people using the park of $250 \%$, therefore on a per head calculation it can be argued that reported crime in Ladywell Fields has fallen. To back this up, perceptions of feeling safe or very safe doubled with nearly $80 \%$ of park users showing themselves to be more at ease with their new surroundings, an increase from under $40 \%$ before the works ${ }^{9}$.

As already mentioned, there was a significant increase in the biodiversity found in Ladywell Fields. This biodiversity attracts a diversity of people. There is little more rewarding than the flash of colour as a kingfisher flies along the river corridor. While running tours of the park for specialists from the Department of the Environment or various European projects, visitors are surprised to see a heron fishing in the river only a stone's throw from a busy railway line or road. One individual from the World Wildlife Fund who had lived in Lewisham 10 years earlier was amazed at a presentation outlining the life in what he had known as a "dead" river. The combination of nature's resilience, a helping hand from residents and partners and a relatively small amount of financial backing from the European Union and the local Council could have such a wide ranging

9 See QUERCUS in Lewisham. Evaluation Report (2018, August). Available at http://www.pceuconsultant.eu/uploads/files/ QUERCUS\%20in\%2oLewisham\%20Evaluation\%2oReport(1).pdf 
and long-lasting impact.

In fact, the work on the northern field and the new channel was only the beginning of the story for Ladywell Fields. Building on the idea that people like to be associated with successful projects, the following years brought a further $£ 2$ million investment from the Mayor for London and the Greater London Authority to continue re-naturalising and opening up the river in the middle and southern fields. More recently the ongoing work to create a space that also acts as flood defence has seen further large-scale investment further upstream as the lessons learnt and so obviously seen in Ladywell are transferred to Beckenham Place Park. This will be achieved through a grant from the UK's National Lottery building on the idea that people make places. The success of Ladywell Fields was also recognised through a number of significant built environment awards; the 2013 Best New Public Space in the London Planning Awards; Winner, Urban Green Space category 2012 and Commended, Public spaces category, New London Awards 2012.

\section{THE LESSONS LEARNED}

Quality open space creates the opportunity for quality interpersonal and intercultural interaction. The dictionary definition of the "inter" prefix provides a number of supporting descriptions: "between", "among", "in the midst of", "mutually", "reciprocally", and "together". In Ladywell Fields this was actively encouraged through the employment of two "waterlink way rangers". Named after the existing walking and cycling paths along the Ravensbourne, these individuals made it their purpose to facilitate interactions. School children visited the park to study the water cycle and the life of rivers, clean up groups, historical and nature societies were encouraged to recruit new members and utilise the changes in the park. One noticeable innovation was the opening at weekends of the Council's store of waders, nets and recording instruments to encourage children and their parents to actually get into the river.

It is also important to note the impact of working in partnership with other agencies, groups and individuals on the success of the project. This was so whether they were the decision-makers or the local agitators; each had a key part to play. Locally the Quaggy Waterways Action Group (QWAG) had long been campaigning for the restoration of Lewisham's rivers and waterways. In some parts of the Council they might have been seen as dreamers or idealists, but their longstanding lobbying to improve the health of the local rivers contributed significantly to the plans for Ladywell Fields. One of the most important interventions came once the project had been delivered. Although initially established to monitor the state of the river Quaggy in the east of Lewisham, they were among the first groups to praise the vision and success of the restoration in Ladywell Fields, seeing it as completely connected to their own vision and setting the benchmark for opportunities to follow.

The national Environment Agency were another key partner. All work involving the water and channels of rivers in England is overseen by them. They have a remit to prevent flooding as well as enhance the natural condition of waterways. The relationship with 
them was not always easy. As the acknowledged experts in the field, they were, at times, suspicious of the Council taking a lead; the situation was too complex, and the specialisms didn't exist outside their organisation. It was a case of building relationships to realise the mutual benefits to be found by working together and, although the partners had different starting points and objectives, a shared set of results would allow all of them to claim some credit and kudos from the project. As the project progressed it became obvious that the inter-agency working was delivering something much better than if they had acted alone, that the different perspectives and rationales for being involved, rather than competing with each other, was creating something unique. In fact, a senior member of the Environment Agency Head Office Team wanted to know how he could "bottle what was happening" in order to be able to take it around the country.

One of the key benefits from organisations working together was the ability to reach different audiences. Combining resources helped prevent consultation fatigue and more importantly provided a wider demographic for each of the participating organisations. Rather than simply "preaching to the converted" the Environment Agency were getting responses from across the community. Additionally, the partners worked together to provide alternative methods of creating interest so, as well as the more obvious public consultations regarding the plans, local people were able to participate in "design charrettes", "river clean up days", "nature conservation" and "theatre and storytelling" using the river as the stage and subject.

\section{SOCIAL COHESION AND INTERCULTURAL DIALOGUE}

Once the new river channel was in place and Ladywell Fields reopened to the public, recorded usage increased by over $250 \%^{10}$. Today, almost 10 years later, this figure has stayed relatively constant. Over that time there has been significant opportunity for members of the community to mix, meet and engage. The author's own experience is that in the neutral surroundings of the park, people are much more willing to engage in conversation, more able to coexist with the differences evident in the wider community. On nearly every occasion I visit the park, and particularly the area around the café, people will strike up conversations. Whenever I host study visits or show interested parties around, park users will join the conversation and be only too happy to give their perspective. In the majority of cases this reinforces the message that is being given; "this park has been transformed"; "I love coming here"; "this is the best money the Council has ever spent".

\section{THE CONCLUSIONS}

It is no coincidence that an improved natural environment, focused on the restoration of a hidden river, has changed the perception of Ladywell Fields from being a

10 See QUERCUS in Lewisham. Evaluation Report (2018, August). Available at http://www.pceuconsultant.eu/uploads/files/ QUERCUS\%20in\%2oLewisham\%20Evaluation\%2oReport(1).pdf 
problem to being a destination for residents. However, more work needs to be done to measure the lasting impact, and the environmental and health benefits that are known to have occurred. While there is information available on improvements to water quality - which was raised from poor to good according to the EU's Water Framework Directive Indicators" - there is very little data to explain the benefits to quality of life. This highlights the gap that still exists between the environment sector and those looking to improve society.

Reported incidents of crime, although staying roughly the same as pre-work levels, when contrasted with the increase in users, shows a significant per head reduction. One interesting observation is that the improvement to people's feelings of safety did not come at the expense of biodiversity and the natural environment. In fact, the initial data collection on completion of the project was that types of habitat had increased and with that the diversity of wildlife had also improved with twice the number of species found in the area. This goes some way towards addressing the either/or argument when it comes to the urban environment. More people does not necessarily equal less wildlife. In fact, the experience of Ladywell Fields shows that having greater exposure to quality landscape and riparian improvements increases an individual's understanding and appreciation of their environment. They become additional eyes and ears, taking pride in the sightings of kingfishers and reporting - the reduced - incidents of pollution.

The Environment Agency, the European Commission and the OECD have all used Ladywell Fields as an example of how good quality environmental improvements can transform urban areas. However, when making presentations to these organisations the idea that people might also benefit, while not a surprise, has simply not been measured. This gap in research needs to be addressed, but it will take a project that bridges the divide that still exists between the different disciplines to do this. Urban river restoration as an idea mirrors the complexities and problems that exist between different sides - in this case societal and environmental - yet shows that interaction, dialogue and finding a shared understanding brings unexpected results.

The same is true of projects focusing on intercultural dialogue. The challenge is to expect multiple benefits from simple interventions, to see the potential in an urban stream rather than covering it up. In the same way, it should be possible to see the value of someone from another background or culture, rather than ignoring or hiding them away.

Through this the urban river becomes not only a metaphor for social mediation but provides a practical place for these interactions to happen. The impact of a quality urban environment on the quality of life for all can be summed up in this quote from the former Mayor for London: "the rejuvenation of Ladywell Fields means the area is now an oasis of calm for people to socialise and relax in"12."

\footnotetext{
"See http://environment.data.gov.uk/catchment-planning/OperationalCatchment/3369/Summary

${ }^{12}$ In the following article by the landscape designers of the scheme: http://www.bdp.com/en/projects/f-l/Ladywell-Fields/ and associated publicity e.g : http://www.landezine.com/index.php/2014/12/ladywell-fields-by-bdp/
} 


\section{BIOGRAPHICAL NOTE}

Paul is an Urban PlaceMaker linking the physical development in a city to its constant societal changes. He is an Expert for the Council of Europe's Intercultural Cities programme and the EU's URBACT Fund. He has over 18 years in managing cross disciplinary transnational projects. He is particularly interested in developing a multi-agency approach to rediscovering the importance of small urban rivers and was instrumental in the ongoing success of the award winning Ladywell Fields and Cornmill Gardens in Lewisham, London.

ORCID: 0000-0003-1708-1946

Email: paul@pceuconsultant.eu

Address: PCEU Consulting Ltd (UK), 25 Stillness Road, London, SE23 ING, UK

* Submitted: $20 / 05 / 2018$

* Accepted: 20/09/2018 